Copyright (C) 2014 by Academic Publishing House Researcher

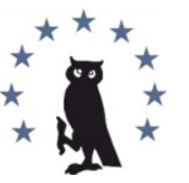

Published in the Russian Federation

European Researcher

Has been issued since 2010.

ISSN 2219-8229

E-ISSN 2224-0136

Vol. 87, No. 11-2, pp. 2013-2021, 2014

DOI: 10.13187/er.2014.87.2013

www.erjournal.ru

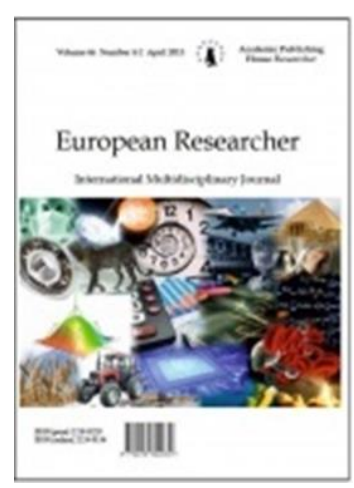

Pedagogical sciences

Педагогические науки

\title{
School Courses as a Motivational Factor for the Implementation of Active Recreation in Adulthood
}

\author{
${ }^{1}$ Beáta Dobay \\ ${ }^{2}$ Elena Bendíková
}

\author{
${ }^{1}$ J. Selye University, Komárno, Slovakia \\ Doctor of Pedagogy \\ E-mail: dobay.beata @selyeuni.sk \\ ${ }^{2}$ Matej Bel University, Slovakia \\ 97401 Banská Bystrica Tajovského, 40 \\ Doctor of Pedagogy, PhD, Assistant professor \\ E-mail: Elena.Bendikova@umb.sk
}

\begin{abstract}
The motivation of sports occupies an even more important role than actually performing physical activities. The Ministry of Education of the Slovak Republic ensures the implementation of several compulsory elective sports courses through different stages of educational institutions. We were curious how these courses - especially school in nature - act upon vacations in adulthood. By examining curricular documents and implementing questionnaire methods - applying „Vacation practice questionnaire” - we questioned the Hungarian language speakers of southern Slovakia $n=2965$. The data were processed using the statistic program SPSS 17. 84.5 \% $(p<0.01)$, of the canvassed took part in school in nature, from which $65,8 \%(\mathrm{p}<0.01)$, rated the time spent there as positive. Amongst the positively valuing 44,2 \% indicated the mountains as a favourite and frequently chosen travel destination. $25 \%$ spends more than four hours hiking. We may say that organizing schools in nature has to be considered as an important event (5-7 days), where the students have fun, wherefore they will choose mountains as their travel destination more frequently, which results in higher physical activity.

Listed partial discoveries are included in the grant: VEGA no. 1/0376/14 Physical activity intervention for the prevention of health of the population of Slovakia.

Keywords: school in nature; sport tourism; curriculum

\section{Introduction}

Slovakia is located in the heart of central Europe, where a wide variety of natural facilities await the demand of tourists (Lauko, 2003). The country ensures high quality vacation opportunities for domestic or foreign tourists with several legal options (Gúčik, 2000, Gúčik et al., 2006, 2007). From September, 2008 the new Educational Law came into effect, which ensures a larger scale of freedom and autonomy for schools. The country indicates the recognition of its
\end{abstract}


natural treasures through scholar education (ISCED $0,1,2$ ) specifically in the curriculum of physical education (Antala, Labudová, 2008; Kršjaková, 2008; Mikuš, Bebčáková, Modrák, 2008). This is quite unique, in comparison with other countries, which reappears as motivation in the vacation destination selection of adults. In most cases this motivation is suggestive in most cases (Bánhidi, 2012). According to Atkinson, Hilgard et al. (2005) suggestive motivation may be described by pleasure or dismissal. The motivation of the self, abilities and skills operate through appropriate motivation (Nagy, 1998).

Applying sports activities is not only influenced by cognitive and motor skills, but also the motivational background of the individual. Applying physical activities throughout the vacation can be linked to the patterns of childhood. This is when motivation, concerning sports are grounded. Positively rated sports courses, experienced in childhood, have impact on later holiday destinations in adulthood (Müller et al., 2007).

Motivation is a very important factor, as to be able to use these physical experiences actively in their free time. By attending various sports courses, sport is linked to a childhood pattern, where the positive feedback from doing sports has effect on the person's later life with great probability. It is important for this motivation to stay in the foreground, as sport may become a powerful tool in the shape of one's personality and health (Dobay, 2007).

\section{Materials and methods}

Our aim is to show what effect school sports camps might have on adult's vacation practices. We unfold the possible outcomes of effects of sports courses, granted by curricula, on vacation practices in adulthood and the time spent on sports activities there.

Our assumptions:

- We assume that those students, who attended sports courses during their studies and had fun there, it appears as an influencing factor in their later life.

- We assume that motivational factors experienced during childhood can be found in a person's adult life.

- We assume that sports activities are an elemental part of summer and winter vacations.

- We assume that from those, who attended school in nature and had positive feelings towards it, more than half chose the mountains as their spot for holidays and applied hiking or touring as a sports activity.

The primary resource was the questionnaire regarding vacation practices. The questionnaire was filled in by inhabitants of southern Slovakia (from Bratislava to Královský Chlmec), anonymously ( $\mathrm{n}=2965)$. During the sampling we used the accidental sampling method. The questionnaire was ready made by the Sports Tourism Section of the Hungarian Sports Science Association. According to the 2011 census, 458464 inhabitants pledged themselves as Hungarian the queried are therefore $0,65 \%$ of them. The number of children may be derived from this number, as we asked the adult population. In this case, the queried may reach the $1 \%$. We assembled the questions in a way that they fulfil the objects proposed by the questionnaire. There are several methods for evaluating the questionnaire. We used the tools of descriptive statistics, mainly spreadsheets to evaluate the gathered primary data. As our first step, we created our datasheet by coding in the received answers. Afterwards, contingency sheets were created to ease the processing of data. The questions of the questionnaire may be divided into three groups: closed questions, using Likert's scale, closed questions and questions regarding personal information. The questionnaire concerns the vacation practices of those, queried. During the processing of the data, we are looking for an answer to the question, whether two nominal or ordinal variables are interrelated. The null hypothesis expresses that there is no connection between two quantitative factors. From among the statistic computer programs we preferred the SPSS 17 data structure management software. The SPSS 17 management software includes through descriptive statistics - the most difficult, several variable, differing mathematical procedures. The pro of this software kit is that we can create simple models and also create their statistic analysis. This environment was used to examine interrelations. As a secondary resource, we used a document analysis by examining the curricula of the Slovak Educational Ministry's educational programs. 


\section{Research results and discussion}

The school curricula in Slovakia describe the organization of sports camps as a compulsoryelective activity, which is included in the Physical Education curriculum. The curricula - ISCED $0,1,2$, and 3 - the aberrations of school age groups and the correlation are assured by thematic units. The curricula of scholastic PE offer an opportunity for the teachers and students to attend various sports courses as part of scholastic education. From among the sports mainly the hiking, skiing and swimming enjoy priority (Melicher, Slezák, 2000). In our case, we opened up achievements in connection with hiking. In each educational institute only those performance expectations may be taught, which correspond with those, stated in the curricula for that specific age group. The aim for kindergarten students - within hiking - is the performance of longer walks and cognition of nature. The monotony tolerance for kindergarten students is very low, therefore walks in the nature should be vivified by interesting activities (Guziová, 2011; Bánhidi, 2007). For elementary school students, this distance is lengthening $(7 \mathrm{~km})$, which can be filled in with conservationist and environmentalist activities (Sivák, 1999). For senior students, basics of cartography are part of hiking (Antala, Labudová, Górny, 2010).

High school students learn the basics of first-aid, next to the previous knowledge. Performances connected with hiking, before 2008 are included in tabulation 1, these were improved by modifying the curricula after 2008, which escalated with more sports activities that can be done outdoors, other than hiking - i.e. riding a scooter, cycling and exhausting the qualities offered by the nature.

Table 1: Formula according to the curriculum, before 2008 (Dobay, 2007)

\begin{tabular}{|l|c|c|c|c|c|}
\hline $\begin{array}{l}\text { School } \\
\text { types }\end{array}$ & Kindergarten & $\begin{array}{c}\text { Elementary } \\
\text { school }\end{array}$ & Senior class & High School & $\begin{array}{c}\text { University-College } \\
\text { (teaching studies) }\end{array}$ \\
\hline Touring & $\begin{array}{c}\text { Perform } \\
\text { 3km with } \\
\text { stops }\end{array}$ & $\begin{array}{c}\text { Perform } \\
10 \mathrm{~km} .\end{array}$ & $\begin{array}{c}\text { Perform } \\
\text { 10 km, basics } \\
\text { of cartography }\end{array}$ & $\begin{array}{c}\text { Perform } \\
10-20 \mathrm{~km}, \\
\text { First-aid }\end{array}$ & $\begin{array}{c}\text { Perform } \\
10-20-30 \mathrm{~km}\end{array}$ \\
\hline
\end{tabular}

The research on the impact of motivation as an effect of scholastic sports courses having impact on vacation practices was done by using this knowledge. The research was done by questioning the population of southern Slovakia. The data of the descriptive statistics are as follows: the questionnaire was filled in by $n=2965$ people, of which $38.5 \%$ were male, the rest $(61,5 \%)$ women. When distributing the queried to age groups, $70 \%$ form the part of active workers. $23 \%$ are below the age 26, while the senior citizens - age 55 and above - form $7 \%$ of those asked. The first section was to answer questions about their social background. More than half on the queried live in a household of 3-4 people. $17.1 \%$ live in families of two. Singles form a relatively small $3.8 \%$. The majority lives in villages ( $53 \%$ ) and only $5 \%$ live in the capital or a big city - with population over 100000 . Those, living in private houses are $47.5 \%$, while those, living in flats (blocks of flats) are $25.7 \%$ (Fig. 1).

We asked how often they go on at least a week of holidays during summer or winter, either abroad or at home. The answers reveal that $45.1 \%$ go on holidays during the winter at home, while those, going abroad are only $23.5 \%$. When looking at summer holidays, the majority - $71.4 \%$ chose foreign countries as a destination; however this figure is only $6.5 \%$ lower than the percentage of holidays spent at home. 


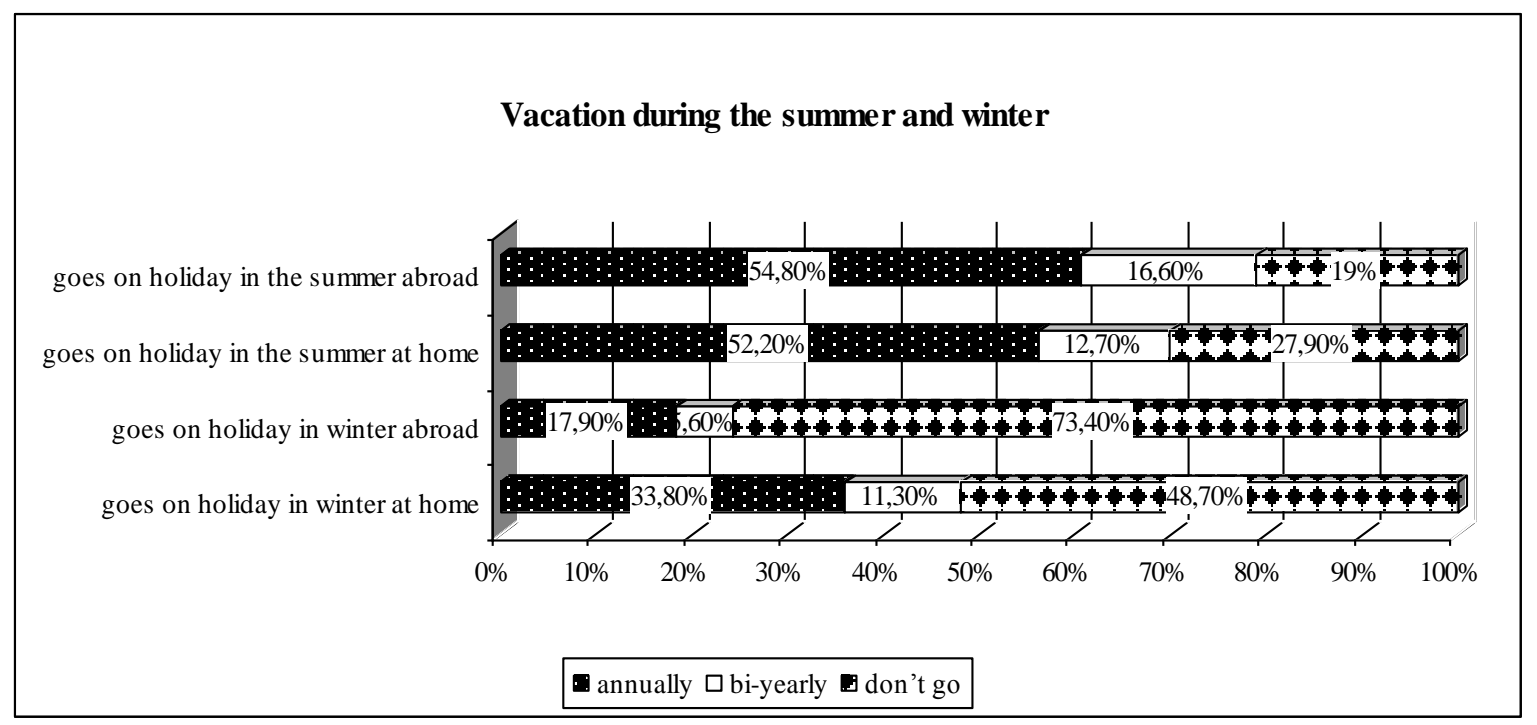

Figure 1. Vacation during the summer and winter

Out of those who pledged mountains as their favourite destination, $28.7 \%$ spend over four hours hiking, $27.9 \%$ touring. $67 \%$ of those, being in favour of mountainous holidays had spent over one hour, hiking. $63.5 \%$ plan hiking during their holidays (Fig. 2).

In the next question group we asked, what sports events they attended as a child, and how they rated them. Answers were quantified with respect to their character and used likert scale. The queried could rate their feelings towards different camps 1-5. Number 5 meant the best rating. All in one, the queried took part in total 12770 sports camps, which means 4.3 courses per person.

Within scholastic education, students first meet school in nature (primary school), where the travel away from home, usually for days. For many, this is the first touristic holiday, let us say, sport touristic vacation. This has notable appreciation all over the country, wherefore $84.5 \%$ of the queried attended school in nature, $86.7 \%$ of them, in different tours. In the case of school in nature, $65.8 \%$ rated it as 'like it very much' or 'like it'.

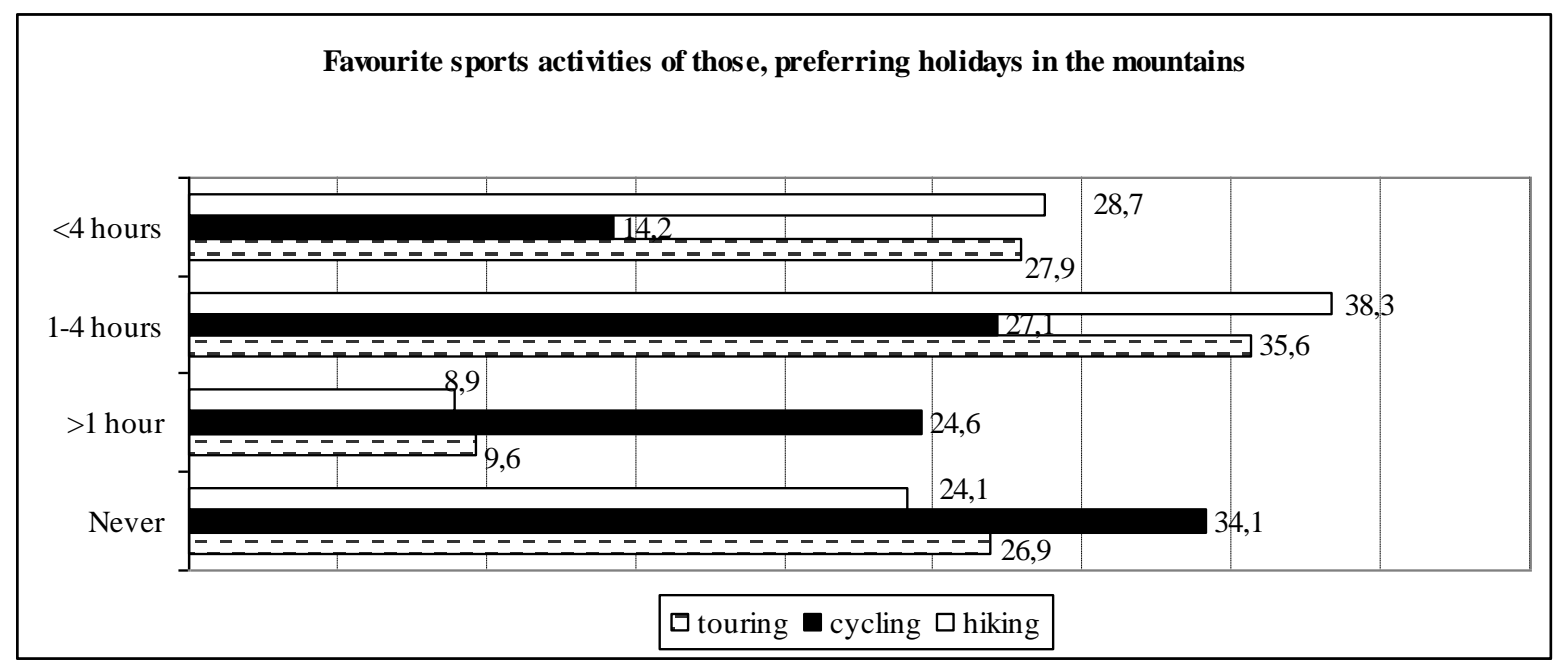

Figure 2. Favourite sports activities of those, preferring holidays in the mountains

Students meet again with hiking during their later studies in high school. $28.9 \%$ rated hiking in general as 'like it very much' or 'like it'. Least of all took part in water sports, of which $13.3 \%$ rated them as their favourite camps. Most of the persons examined (91.5\%) took part in elementary school ski training, and high school ski course (Fig. 3). Out of those, who ever attended such camps, rated as 'don't like it' only in small portions. 


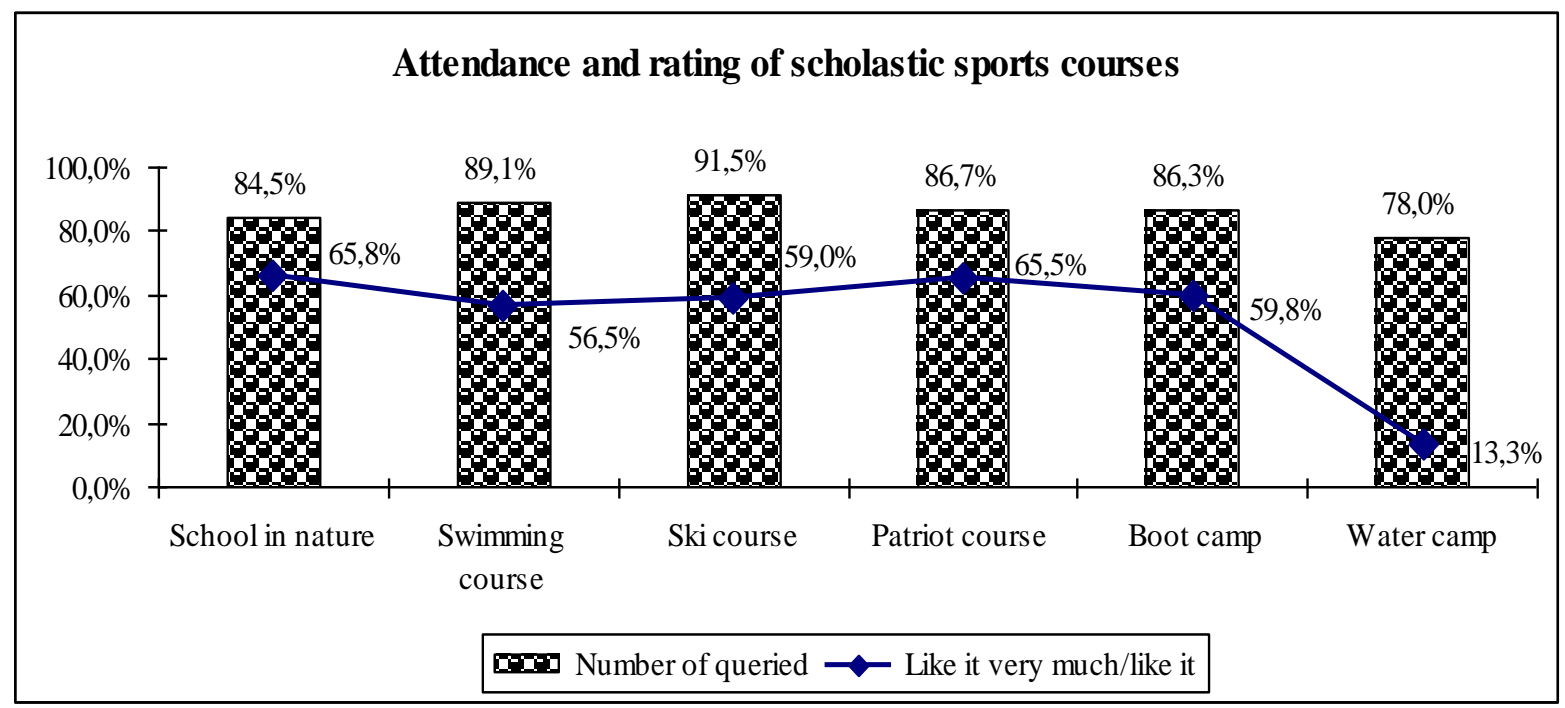

Figure 3. Attendance and rating of scholastic sports courses

In the next evaluation we dealt with the experiences of those responses, who took part in school in nature. Students of elementary schools attended schools in nature. These experiences are the oldest for them. Positive effects, gained there, could have faded the most. $65.8 \%$ of those, who took part in schools in nature, rated their memories as positive. $44.2 \%$ of the queried choose the mountains as their favourite destinations (Fig. 4).

The majority of the queried choose inland for their winter holiday destination, and also tend to stay inland for the summer holidays, where the mountains play an important role.

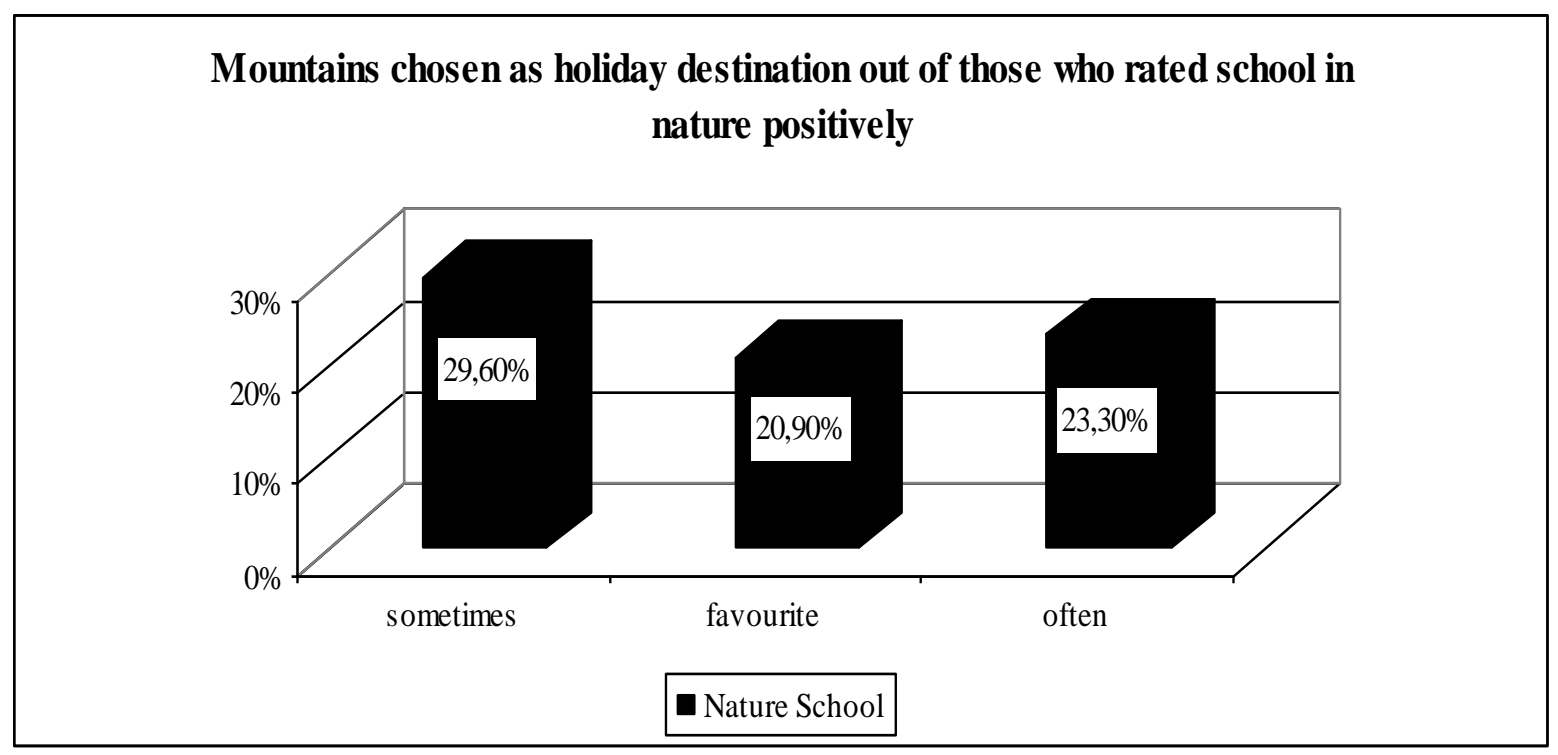

Figure 4. Mountains chosen as holiday destination out of those who rated school in nature positively

Those responders, who evaluated school in nature positively and choose mountains as their holiday destination, choose the following sports activities during their vacation: $25 \%$ spends more then four hours hiking, and $24.5 \%$ touring. $48.8 \%$ cycles less than an hour (Fig. 5).

All in all, responders use the well-appointed hiking courses, where they can find an appropriate for every age category. Over $14.000 \mathrm{~km}$ of appointed courses are available in the country. In Slovakia, there are unique and organic signs, providing safe hiking for tourists. Students get to know this information during their attendance in schools in nature. Appropriate, interesting programs are provided for families as well, which capture the attention of children. There are courses for baby carriages as well. Today, there are $30.8 \mathrm{~km}$ of course ready for them 
(Kollár, 2007). Results show that those, who attended scholastic natural programs (84.5\%) and had a good time there (65.8 \%), later chose mountains as their holiday destination, and did sports there on purpose, wherefore $24.5 \%$ of them hike over 4 hours there.

According to the data from 2009, 59 \% of the country is mountains, $41 \%$ forest (Capuliak, 2011). These natural opportunities and the infrastructure belonging to it provide an opportunity for the scholastic natural programs to be brought into effect.

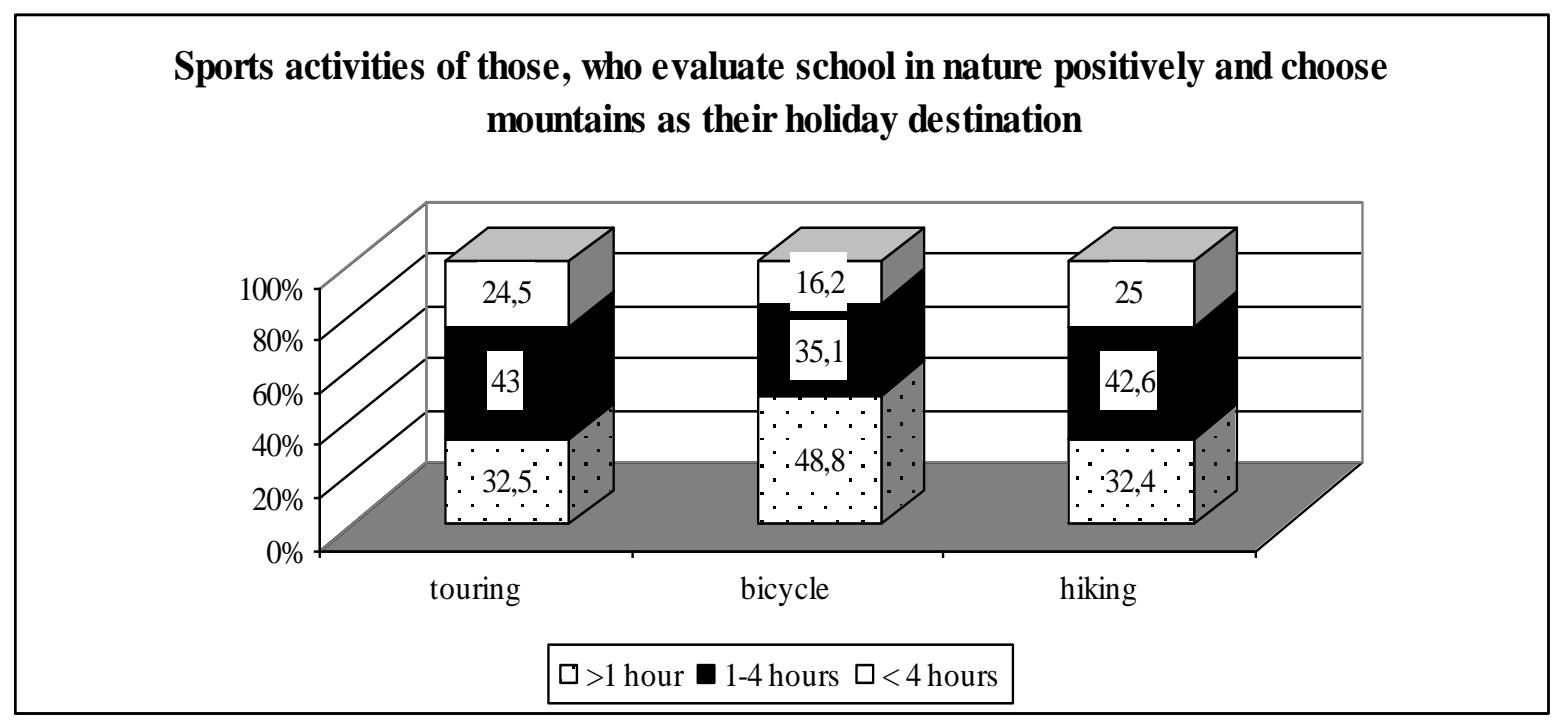

Figure 5. Sports activities of those, who evaluate school in nature positively and choose mountains as their holiday destination

In the case of hiking, the appointed tourist courses $(14.000 \mathrm{~km})$, appropriate special programs, theme parks add to the construction. Out of these, the following address small children: Wildlife - woodchuck country, Woodchuck at the ball, the Bear days. The theme park called Little Red Riding Hood in Jasná, in the Low Tatras. The cableways of the company Tarzania offer exciting sports activities for senior elementary and high school students, out of which ten still function: Trenčín, Hrabovo,Vel'ký Meder, Tále, Alpinka, Jasná, Skalica, Vlčkovce, Ostrá Skala, Devínska (SACR, 2009; Hoholíková, 2012).

Hiking is an important part of Slovakia's physical education, a complex activity, which has the main aim to endear beauties of nature, show cultural memories (Ludvík et al., 1986). A similar definition is used by Rozim, Krystoň (2001), Bendíková (2010), Žiškay et al. (1999) according to which, touring is called a special trip, with parts as movement and gaining knowledge. Doing sports in nature is one of the most widely used movement activities on the field of recreation, independently from age, gender and social background (Pach, 2009), therefore they can become integral parts of holidays. Movement is one of the best devices of spiritual recreation (Cavill, Kahlmeier, Racioppi, 2006).

Sports activities that can be done in the nature received an important role in the curricula before and after (ISCED o, 1, 2, 3) 2008 as well as various courses and camps. Emphasizing the desires of the era and showing the new ways of sports. School in nature for high school students is under regulation of paragraph 2009/282, accepted on July 24, 2009, which involves the measure $245 / 2008$ with respect to excursions, healthy lifestyle, environmentalist course and outdoor sports activities. It states that on these courses there needs to be at least 15 active hours, which can be varied out by commuting daily, or as a course, which can take up to five working days. Many educational institutions use this option, as it is common even for kindergartens to organize sports courses. Kindergartens can organize kindergarten in nature and winter sports courses for students from the age of five. Therefore measures also confirm the opportunity for students to take part in sport courses in the nature (Modrák, Lajčák, Povrazník, 2010). There were researches made in Slovakia about outdoors sports activities, like Bendíková (2012) with 12 - 15 year old students and Paugschová, Görner, Bendíková (2008) with 16-18 year old students the reaserach was done in 1987 (Zajac, Žiškay, 1987) and in $2009(\mathrm{n}=8$ 400). These age groups show a certain fallback, 
compared to the year 1987. There was a rise: $15 \%$ with swimming and sports games, $13 \%$ with cycling and $10 \%$ with ice skating. This may be thanked to the fact that there is a wider range of sports accessories with families than in 1987. Sport is mostly connected to childhood patterns and systematic physical training is likely to stay in later stages of life as well. It is important for this motivation to stay in the foreground, as sport may become a powerful tool in the shape of one's personality and health (Bollók et al., 2011).

\section{Conclusion}

The attention of recent youth has to be raised to movement's positive effect on the body and mind. A good instrument for this may be the sports courses, supplied by the curricula of the Slovak Ministry of Education. We can make them interesting by organizing them and applying project methods. By the positive effects we can achieve positive motivation that will have impact on their later vacation practices in the adulthood. This idea is confirmed by our evaluated questionnaire of the Hungarian people in southern Slovakia, wherefore those, who attended these courses and obtained positive experiences, choose the mountains and perform active physical activities more often.

\section{References:}

1. Antala, B., Labudová, J. \& Górny, M. (2010). Hodnotiaca činnost’ v telesnej a športovej výchove. Bratislava: Comenius University in Bratislava. 2010, pp. 61-130.

2. Antala, B. \& Labudová, J. (2008). Kurikulum telesnej a športovej výchovy pre vyšší sekundárny stupeň vzdelávania. Telesná výchova a šport, 18(2), 2008, pp. 4-7.

3. Atkinson, R., Hilgard et al. (2005). Pszichológia-harmadik átdolgozott kiadás. Budapest: Osiris tankönyvkiadó. 2005, pp. 91-326.

4. Bánhidi, M. (2007). A mozgásos játék kisgyermekkorban, In Dobay Beáta, Az óvodai testnevelés alapjai-második bővített kiadás. Komárno: Selye János University. 2007, pp.193-214.

5. Bánhidi, M. (2012). Rekreológia alapismeretek I., Rekreológia Leisure Science, 2(3),2012, pp. 28-30.

6. Bendíková, E. (2010). Kurikulárna transformácia telesnej a športovej výchovy a postoj študentiek stredných škôl $\mathrm{k}$ zdraviu a pohybovým aktivitám. In Prvé kroky kurikulárnej transformácie v predmete telesná a športová výchova : zborník z vedeckej konferencie. Bratislava : Univerzita Komenského, Fakulta telesnej výchovy a športu, 2010, pp. 65-72.

7. Bendíková, E. (2012). Obsahová náplň, úroveň vedomostí a zručností žiakov základných škôl z učiva Ochrana človeka a prírody. Olomouc : Univerzita Palackého, 2012, 111 p.

8. Bollók, S., Takács, J., Kalmár, Zs. \& Dobay, B. (2011). External and internal sport motivations of young adults. Medical Human Kinetics, University of Physical education, Warsaw, Poland, 3(1), 2011, pp. 101-105.

9. Capuliak, J. (2011). Medzinárodný rok lesov. Krásy Slovenska, Klub slovenských turistov , Bratislava, 88(5-6), 2011, pp. 20-21.

10. Cavill, N., Kahlmeier, S. \& Racioppi, F. (2006). Physical activity and health in Europe. Geneve : WHOPress, 2006, pp. 34.

11. Dobay, B. (2007). Szlovákia sportturisztikai adottságai s annak hatása az iskolai tanterv által szervezett táborozásokra. Magyar Sporttudományi Szemle, 8(31), 2007, pp. 18.

12. Guziová, K. (2011). Ešte raz o predprimárnom vzdelávaní. Predškolská výchova, 65(6), 2011, pp. 1-6.

13. Gúčik, M. (2000). Základy cestovného ruchu. Banská Bystrica: ŠVK. 200o, pp. 19-68.

14. Gúčik, M., Malachovský, A., Patúš P., Maraková V. \& Š́pková I. (2006). Manažment cestovného ruchu. Banská Bystrica : Slovak-Swiss Tourism. 2006, pp. 190-207.

15. Gúčik, M., Hanesová, L., Chlumecká, V., Hrčková, M., Kmeco, L., Patúš, P., Petrík, I., Šípková, I.,Tvrdoňová, K. \& Vetráková, M. (2007). Manažment regionálního cestovného ruchu. Banská Bystrica : Slovak-Swiss. Tourism. 2007, pp. 37-43. Hoholíková, T. (2012). Jedným dychom. TATRY, 51(4), 2012, 24 pp.

16. Kollár, D. (2007). Tatry bez bariér. Krásy Slovenska, Klub slovenských turistov, 84 (9-10), pp. 5 .

17. Kršjaková, S. (2008). Nové kurikulum telesnej výchovy v primárnom stupni vzdelávania. Telesná výchova a šport, 18(2), 2008, pp. 2-4. 
18. Lauko, V. (2003). Fyzická geografia Slovenskej Republiky. Bratislava: MAPA Slovakia, Škola s.r.o. pp. 42-58.

19. Ludvík, M. et al. (1986). Malá encyklopédia turistiky. Praha: Olympia. 1986, 345 p.

20. Mikuš, M., Bebčáková, V. \& Modrák, M. (2008). Aktuálne problémy realizácie nových učebných osnov v praxi. In Telesná výchova a šport, zdravie a pohyb Prešov. 2008. pp. 41-46.

21. Modrák, M., Lajčák, V. \& Povrazník, K. (2010). Metodika organizovania lyžiarskych výcvikov (ZŠ) a lyžiarskych kurzov (SŠ) Bratislava: Regionálne Stredisko Prešov. 2010. pp. 4-32.

22. Müller, A., Széles-Kovács, Gy., Seres, J., Bocz, Á., Hajdú, P., Sütő, L., Szalay, G., Szabó, B. \& Juhász, I. (2007). A sporttáborok szerepe az Eszterházy Károly Főiskolán. Acta Academiare Pedagogicae Agriensis, Section Sport, Eger, 34, 2007, pp. 105-117.

23. Nagy, J. (1998). A kognitív motívumok. Iskolakultúra, 10, 1998, pp. 59-76.

24. Pach, M. (2009). Športy v prírode ako nástroj výchovy a vzdelávania. Telesná výchova \& šport, 19(2). 40 p.

25. Paugschová, Görner, K. \& Bendíková, E. (2008). The Attitude and the Relation of physical Education Teachers of the middle Slovak Region to the hiking and outdoor Sports. In Sport a kvalita života 2008 Sport and Quality of Life 2008: sborník příspěvků z mezinárodní vědecké konference, Brno: MU.pp. 16.

26. Rozim, R. \& Krystoň, M. (2001). Význam motivácie v práci stredoškolského učitel’a vo vztahu k telesnej výchove. In Acta Universitatis Mathiae Belii Telesná výchova a šport, Vol. 3., No. 3. Banská Bystrica: PF UMB. pp. 81-89.

27. SACR (2009). Vybrané zariadenia pre aktívnu dovolenku na Slovensku /on line/. Retrieved on 11th August 2011. From http://new.sacr.sk/fileadmin/ user_upload/Slovensko/ Nase_tipy/adrenalin/Adrenalin-SJ-09.pdf

28. Sivák, J. (1999). Obsahový a výkonový štandard z telesnej výchovy pre 1. stupeň základnej školy. Ministerstvo školstva Slovenskej republiky, č. 240/99-41,1999, pp. 2-3.

29. Zajac, A. \& Žiškay, J. (1987). Turistika v socialistickom spôsobe života mládeže SSR Bratislava : Slovšport. 45 p.

30. Žiškay, J., Šimonek, J., Švajda, Š. \& Záhorec, J. (1999). Orientačný energetický výdaj pri formách pešej turistiky, Miesto a význam turistiky a športov v prírode pri rozvoji telesnej zdatnosti a psychickej odolnosti mládeže a dospelých. Bratislava: Comenius University in Bratislava. $137 \mathrm{p}$.

\title{
Школьные курсы как фактор мотивации для реализации подвижного отдыха в зрелом возрасте
}

\author{
${ }^{1}$ Беата Добай \\ ${ }^{2}$ Елена Бендикова
}

\begin{abstract}
${ }_{1}$ Университет им. Й. Селые, Словакия
Братиславска цеста № 3322, г. Комарно

Доктор педагогики

E-mail: dobay.beata@selyeuni.sk

2 Университет им. Матея Бела, Словакия

974 01, г. Банска Быстрица, ул Тайовскехо 40

Доктор философии, доцент, магистр

E-mail: Elena.Bendikova@umb.sk
\end{abstract}

Аннотация. Мотивация играет ключевую роль в детском возрасте с точки зрения реализации двигательных активностей в образе жизни взрослого человека. Одна из дисциплин, которая уделяет внимание спортивным курсам, является школьная физкультура 
и спортивное воспитание на разных ступенях развития учеников. Курс «Обучение на природе» принимает участие в создании позитивного отношения к двигательной активности в зрелом возрасте. Он был целью нашего исследования при помощи анкеты «Отдых», в которой принимали участие взрослые люди, жители южной Словакии в количестве 2965 человек. Данные анкет были обработаны статистической программой SPSS 17. Исследования указывают на значимость спортивных курсов в рамках обязательного образования учеников 84,5 \% (р<0.01), которая в значительной мере трансформируется и в зрелый возраст 65,8 \% (p<0.01), где самой распространенной активностью является туризм.

Ключевые слова: обучение на природе; туризм; учебный план. 